九州大学学術情報リポジトリ

Kyushu University Institutional Repository

\title{
Development of the Rotating Type Grain Sterilizer using Infrared Radiation Heating
}

Hamanaka, Daisuke

Departmetn of Bioproduction Environmental Science, Kyushu University

Uchino, Toshitaka

Departmetn of Bioproduction Environmental Science, Kyushu University

Inoue, Ayumi

Graduate School of Bioresource and Bioenvironmental Sciences, Kyushu University

Kawasaki, Kohe i

Graduate School of Bioresource and Bioenvironmental Sciences, Kyushu University

他

https://doi.org/10.5109/9290

出版情報：九州大学大学院農学研究院紀要. 52 (1)，pp. 107-110，2007-02-28. Faculty of Agriculture, Kyushu University

バージョン :

権利関係 : 


\title{
Development of the Rotating Type Grain Sterilizer using Infrared Radiation Heating
}

\author{
Daisuke HAMANAKA*, Toshitaka UCHINO, Ayumi INOUE ${ }^{1}$, Kohei KAWASAKI ${ }^{1}$ \\ and Yoshiaki HORI
}

\author{
Laboratory of Postharvest Science, Devision of Bioproduction System Science, \\ Department of Bioproduction Environmental Science, Kyushu University. \\ Fukuoka 812-8581, Japan \\ (Received November 10, 2006 and accepted December 1, 2006)
}

\begin{abstract}
We developed a grain sterilizer equipped with infrared radiation heating (IRH), and examined the disinfecting effect on wheat grain with various initial moisture contents (IMC). The greater microbicidal effect of IRH was obtained when the IMC of sample grain was high. When treatment was carried out a third time, more than 99\% of initial microbial counts had been destroyed at higher IMCs. Even when the treatment was repeated twice, no significant increase in the fat acidity of wheat grains was obtained in comparison with the control sample at an IMC of either 14 or $24 \%$ (w.b.) $(p<0.05)$. However, the germination rate was markedly decreased as the treatment was repeated, especially at the higher IMC.
\end{abstract}

\section{INTRODUCTION}

In order to extend the storage periods of grain crops, some chemical antimicrobial agents have been widely applied before and during storage (Hocking and Banks, 1991; Ramakrishna et al., 1991; Andrews et al., 1997). Although the microbiological safety of grain crops can be achieved by use of chemical agents, there is some risk of residual chemical agents, and this is not acceptable to the consumer. Therefore, in recent years, some physical methods that have little detrimental effect on human health and the environment have been suggested. Various sterilizers based on physical techniques have been suggested for disinfection of grain crops. Hayashi and Todoriki (1999b) reported the application of a low-energy electron beam (soft electron) in the surface disinfection of various dried materials, and the development of a continuous grain sterilizer. This sterilizer appeared to have little effect on the internal quality of the materials tested (Hayashi and Todoriki, 1999a). Yamanaka (1998) suggested the sterilization of powders and granules by superheated steam; some kinds of bacterial spores (bacilli) on these materials were inactivated within short time. In addition, we have demonstrated the possibility of the application of infrared radiation heating (IRH) to the surface disinfection of grain crops in a batch system (Hamanaka et al., 2003); 99\% of the initial count of microorganisms of wheat and soybean was killed by a few seconds of IRH treatment.

In the present study, we newly developed an IRH grain sterilizer for continuous treatment, and then the disinfecting performance and effect on the internal

1 Laboratory of Postharvest Science, Devision of Bioproduction System Science, Department of Bioproduction Environmental Science, Graduate School of Bioresource and Bioenvironmental Sciences, Kyushu University

* Corresponding author (E-mail: hamanaka@bpes.kyushu-u. ac.jp) quality of wheat grain were investigated. In addition, the effect of the initial moisture content of wheat grain on the efficiency in killing the microorganisms was investigated, since in an in vitro study initial equilibrium relative humidity of the air surrounding Bacillus subtilis spores affected their resistance to IRH treatment (Hamanaka et al., 2005, 2006).

\section{MATERIALS AND METHODS}

\section{IRH grain sterilizer}

Fig. 1 shows the schematic diagrams of the grain sterilizer assembled in the present study. It comprised a

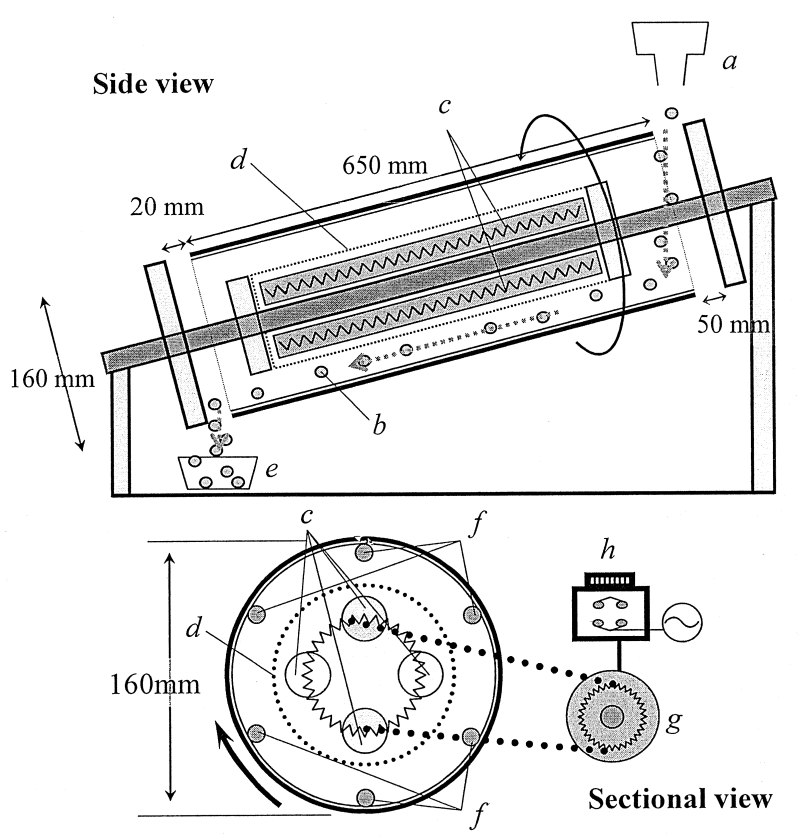

Fig. 1. Schematic diagrams of the rotary drum grain sterilizer. Arrows (n) indicate the direction of the flow material.

$a$, hopper; $b$, test material; $c$, infrared ray tube; $d$, mesh screen; $e$, gathering tray; $f$, agitating pipe; $g$, electric motor; $h$, transducer 
cylinder (length: $650 \mathrm{~mm}$, inside diameter: $160 \mathrm{~mm}$ ) rotated by an electric motor. The inner surface of the cylinder was covered with aluminum sheeting, and four $0.5 \mathrm{~kW}$ infrared heaters $(330 \times \varphi 12 \mathrm{~mm}$, Toshiba, SR-1003T, Japan) were set at the center of the drum. The peak wavelength and peak energy of heater were $2100 \mathrm{~nm}$, and $0.6 \mu \mathrm{W} \mathrm{cm} \mathrm{cm}^{-1}$, respectively. The drum was variously inclined for sliding sample grains down on its inner surface (a constant angle of $\tan ^{-1} 0.25$ was set in present study). In order to uniformly irradiate the sample grain, the inner wall of the drum was equipped with six stainless steel rods (diameter is $5 \mathrm{~mm}$ ) to agitate sample grains during treatment. The drum rotating speed was fixed at 6.9 revolutions per minute throughout this study. The treatment period, which was defined as the period from entry of the sample grain into the drum to its exit from the drum, was about $50 \mathrm{~s}$. In order to obtain greater microbicidal efficiency, the IRH treatment was carried out once and repeated once or repeated twice after the grains had been cooled in a refrigerator at $4^{\circ} \mathrm{C}$ for $30 \mathrm{~min}$.

\section{Preparation of sample}

Wheat grains (Triticum aestivum L., cv. (Chikugoizumi'), harvested at Kyushu University farm in Fukuoka, were used. The moisture content of the harvested wheat was about $13 \%$ (w.b.). In order to investigate the effect of initial moisture content (IMC) of wheat on the microbicidal efficiency of IRH, various IMC levels of wheat grain were prepared. Hydrated samples were prepared by addition of suitable amounts of sterile distilled water in a plastic tray, and the tray was kept in a refrigerator at $4{ }^{\circ} \mathrm{C}$ for $24 \mathrm{~h}$ to absorb distilled water uniformly. IMCs of hydrated wheat grains were from 14 to $24 \%$ (w.b.).

\section{Microbial count}

In each trial, the amount of wheat grains used was $150 \mathrm{~g}$. The treated sample was immediately packed in a sterile polyethylene bag, and cooled in a refrigerator at $4{ }^{\circ} \mathrm{C}$ for $30 \mathrm{~min}$. A $10-\mathrm{g}$ amount of the treated sample was put in $100 \mathrm{ml}$ of sterile $0.5 \%(\mathrm{w} / \mathrm{v}$ ) peptone water (Wako Pure Chemical Co. Ltd., Osaka, Japan), and then strongly rinsed by stirring for $5 \mathrm{~min}$. This rinsed peptone water was used as a microbial suspension. A 0.1-ml volume of microbial suspension appropriately diluted was spread on plate count agar (5 g tryptone (Difco); $1 \mathrm{~g}$ dextrose (Wako Pure Chemical); $2.5 \mathrm{~g}$ yeast extract (Difco); $15 \mathrm{~g}$ agar powder (Wako Pure Chemical); $1000 \mathrm{ml}$ distilled water), and these plates were incubated at $25^{\circ} \mathrm{C}$ for $48 \mathrm{~h}$. After incubation, the colonies that had appeared were counted, and the survivals $\left(\mathrm{N} / \mathrm{N}_{0}\right)$ were calculated. Where, $\mathrm{N}$ and $\mathrm{N}_{0}$ are the counts of surviving and initial microorganisms. Initial microbial count of wheat was about $10^{3}$ to $10^{4}$ colony forming unit per gram $\left(\mathrm{cfu} \mathrm{g}^{-1}\right)$ in any trial.

\section{Fat acidity}

A 60-g amount of treated wheat grains was ground in a flour miller (Tiger Co., SKL-A250, Osaka, Japan) for
$3 \mathrm{~min}$, and fatty acid was extracted in $150 \mathrm{ml}$ of toluene in a 300-ml Erlenmeyer flask with a rotary shaker (Tokyo Rikakikai Co. Ltd., MMS-310, Tokyo, Japan) at $110 \mathrm{rpm}$ for $30 \mathrm{~min}$. The amount of extracted fatty acid was measured by titration with $0.05 \mathrm{~mol} \mathrm{l}^{-1}$ of potassium hydroxide.

\section{Germination rate}

One-hundred grains each of treated and untreated samples were placed on filter paper fully saturated with sterile distilled water in a plastic Petri dish, and kept at $25^{\circ} \mathrm{C}$ for 1 week. Germination rate was defined as the percentage number of grains that germinated within 1 week. The filter paper was moistened daily by application of distilled water.

\section{Water activity}

After cooling the sample grains down to room temperature (c.a. $25^{\circ} \mathrm{C}$ ), a 20 -g of sample grains was picked up in plastic Petri dish $(9 \times \varphi 50 \mathrm{~mm})$. Water activity at $25^{\circ} \mathrm{C}$ was measured by the Aw measuring system (ROTRONIC Logistics Ag, Hygromer C94, Bassersdorf, Switzerland).

\section{Statistical analysis}

Data for survival in this study represent the mean of five experimental replications. Also, data for fat acidity and germination rate represent the means of three replications. Significant differences among IRH treatments were determined by $t$-test.

\section{RESULTS AND DISCUSSION}

Fig. 2 shows the relationship between the IMC and the survival of microorganisms of wheat samples. The resistance of microorganisms on the grain surface to IRH was markedly affected by the IMC. With a single IRH treatment, although more than 90\% of the initial micro-



Fig. 2. Relationship between survival of wheat grains treated by grain sterilizer and their initial moisture content (IMC). one pass through the sterilizer; $\square$ two passes; $\boldsymbol{\Delta}$ three passes. Vertical bars (not shown when masked by the graph symbol) represent standard error $(n=5)$. 
bial population was killed at $24 \%$ (w.b.) IMC, there was little microbicidal effect at $14 \%$ (w.b.) IMC. The measured water activity $\left(\mathrm{a}_{\mathrm{w}}\right)$ was in the range $0.7-0.93$ at 14-24\%(w.b.) IMC (Table 1). Thus, it appears that many kinds of microorganisms that exist on the surface of what grains are sensitive to IRH at higher IMC. We have previously reported (Hamanaka et al., 2005) that subjected to the same infrared heater as that used in the present study, the IRH resistance of Bacillus spores was affected by the surrounding $\mathrm{a}_{\mathrm{w}}$, with the resistance being lower at higher $\mathrm{a}_{\mathrm{w}}\left(>0.8 \mathrm{a}_{\mathrm{w}}\right)$.

Table 1. Relationship between initial moisture content (IMC) and water activity of wheat grains

\begin{tabular}{cccccc}
\hline IMC (\%w.b) & 14 & 15 & 16 & 18 & 24 \\
\hline Water activity & 0.70 & 0.74 & 0.74 & 0.84 & 0.93 \\
\hline
\end{tabular}

When the IRH treatment was carried out a second time, no increase in microbicidal effect was obtained as compared with the single treatment in any one IMC condition. However, when treatment was carried out a third time, the microbicidal effect was significantly greater $(p<0.05)$ than with the single treatment in any one IMC condition; more than 99\% of initial microbial counts had been destroyed at higher IMCs (18 and $24 \%$ (w.b.)). These results support our previous study, which reported that intermittent IRH treatment reduced the microbial counts on wheat and soybean grains in a batch system (Hamanaka et al., 2003). The greater mircobicidal effects could be caused by the extension of the total time during which microorganisms on wheat grains were exposed to lethal temperatures $\left(>100^{\circ} \mathrm{C}\right)$, especially at the higher IMC condition.

Even when the treatment was repeated twice, there was no significant increase in the fat acidity of wheat grains compared with the control sample at an IMC of either 14 or $24 \%$ (w.b.) $(p<0.05)$ (Fig. 3). However, the germination rate was markedly decreased as the treatment was repeated, especially at the higher IMC (Fig.



Fig. 3. Effects of the IRH treatment on the fat acidity of wheat grains. Initial moisture contents were (ם) 14 and ( $\square$ ) 24\%(w.b.). Vertical bars represent standard error $(n=3)$.



Fig. 4. Effects of the IRH treatment on the germination rate of wheat grains. Initial moisture content were 14 ( $\square$ ) and 24\% (w.b.) ( $\square$ ). Vertical bars represent standard error $(n=3)$.

4). Some essential enzymes involved in wheat germination systems contained in the germ could be inactivated by IRH treatments. Moreover, the excessive moisture accelerated the decline in germination. These results could indicate that the almost surface layer part of the wheat grain (ex. aleurone tissue), where the enzymes essential for germination are produced, was damaged by the thermal energy of infrared rays during treatment.

In conclusion, some disinfectant effects were obtained by use of this grain sterilizer. However, excessive IRH treatment can lead to degradation of the internal quality of wheat grains, especially at high IMC. Therefore, more investigations of optimum conditions for this (or an upgraded) sterilizer are needed in order to achieve a product for the food industry that is microbiologically safe but with undamaged grain quality.

\section{ACKNOWLEDGEMENTS}

We would like to express our gratitude to IWASAKI Electric Co., Ltd., for measuring the radiation spectrum of heater. This work was supported by a Grand in Aid for Scientific Research in 2004 from the Ministry of Education, Science, Sports and Culture of Japan.

\section{REFERENCES}

Andrews, S., D. Pardoel, A. Harun, and T. Treloar 1997 Chlorine inactivation of fungal spores on cereal grains. Int. J. Food Microbiol., 35: 153-162

Hamanaka, D., T. Uchino, W. Hu, E. Yasunaga, and H. M. Sorour 2003 Effects of infrared radiation on the disinfection for wheat and soybean. J. Jpn Soc. Agric. Mach., 65: 64-70

Hamanaka, D., T. Uchino, N. Furuse, and S. Tanaka 2005 Inactivation effect of infrared radiation heating on bacterial spores pretreated with various water activities. Biocontrol Sci., 10: 61-65

Hamanaka, D., T. Uchino, N. Furuse, W. Han, and S. Tanaka 2006 Effect of the wavelength of infrared heaters on the inactivation of bacterial spores at various water activities. Int. 
J. Food Microbiol., 108: 281-285

Hayashi, T., and S. Todoriki 1999a Continuous grain rotator designed for soft-electron sterilization. J. Jpn Soc. Food Sci. Technol., 46: 422-427

Hayashi, T., and S. Todoriki 1999b Effects of soft-electrons on the microbial counts and germination of seeds of radish sprout (Daikon) and alfalfa. J. Jpn Soc. Food Sci. Technol., 46: 754-757

Hocking, A. D., and H. J. Banks 1991 Effects of phosphine fumigation on survival and growth of storage fungi in wheat. J. Stored Products Res., 27: 115-120

Ramakrishna, N., J. Lacey, and J. E. Smith 1991 Effect of surface sterilization, fumigation and gamma irradiation on the microflora and germination of barley seeds. Int. J. Food Microbiol., 13: 47-54.

Yamanaka, Y. 1998 Advancement in superheated steam sterilization technology for powder and granule. Food processing and ingredients, 33: 9-13 